\title{
Pericardial Effusion in Dengue Haemorrhagic Fever
}

\author{
by
}

J.M.CH. PELUPESSY*, EVIETA RANTE ALLO T*. and SANTA JOTA**

(From the Department of Child Health* and the Department of Internal Medicine,*, Medical Faculty, Hasanuddin University, Ujung Pandang)

\begin{abstract}
Acute shock in severe dengue haemorrhagic fever (DHF) may occur concurrently with accumulation of fluid in serous body spaces such as pleural, peritoneal and pericardial cavities.

Echocardiography is a non-invasive diagnostic procedure which is sensitive to detect even a small quantity of pericardial effusion.

The chest radiogram in two reported cases of DHF associated with severe shock revealed that almost half of the pleural cavity was filled with fluid. Although no signs of pericardial effusion could be determined on physical examination, ECG and radiological procedures, a small amount of fluid was clearly seen on echocardiogram.
\end{abstract}




\section{Introduction}

DHF is an acute infectious disease, caused by dengue virus which is classified in group B of arthropod-borne viruses. DHF frequently occurs as epidemics, more often in children under fifteen years of age, in the South-East Asian Pacific regions and accounts as the eightth leading cause of illnesses in ten tropical countries of Asia (Sumarmo, 1983).

DHF was first observed in Indonesia by Partana et al. in 1968 in Surabaya though its virological identification was not confirmed until 1970.

The presence of pleural effusion supports the diagnosis of DHF (Tamaela and Karjomanggolo, 1982).

We report two cases of DHF associated with pleural and pericardial effusion.

\section{Case 1}

I, an eleven-year-old Buginese girl entered the Department of Paediatrics, Ujung Pandang General Hospital on May 11, 1986 with the following history: continuous fever of 5 days duration with running nose and coughing. She also vomited frequently and complained of headache, stomach discomfort, myalgia, arthralgia and loss of appetite.

Two days before admission she developed epistaxis and rash on the lower limbs and chest. Stool was normal and micturition diminished.

On physical examination she looked severely ill, irritable and was undernourished (BW $25 \mathrm{~kg}$, BH $137 \mathrm{~cm}$ ). The body temperature was $38.5^{\circ} \mathrm{C}$, pulse rate 144 / minute, respirations $36 /$ minute and blood pressure $80 / 50 \mathrm{mmHg}$, with the presence of cold and clammy skin. Petechiae were noted on the lower extremities and chest. Heart : upper border : 3rd intercostal space; left border : left medioclavicular line; right border : right parasternal line. The ictus was palpable on the left border. Thrill was not noted. Left and right ventricular activity were normal. Heart sounds were normal and regular. Murmurs or friction rub were not heard. The lung revealed normal sounds without rales. The liver and spleen were not palpable, so were the lymphnodes not enlarged.

Blood examination revealed $\mathrm{Hb} 15 \mathrm{~g} / \mathrm{dl}$, platelets 44,000 ul Hct I $47 \%$, Hct II $48 \%$, bleeding time 12 minutes. X-ray film of the chest in the right lateral decubitus position showed an opaque thickening of about $1 \frac{1}{2}$ $\mathrm{cm}$ on the right and effusion filling about a quarter of the right pleural cavity. Hazy appearance was found in the right \& left hilus and right and left paracardial regions. CTR was 0.40 .

Diagnosis : The child was diagnosed as suffering from DHF grade III and was given Lactated Ringer $20 \mathrm{ml} / \mathrm{kg} /$ hour (160 drops/min) intravenously.

On the 2nd hospital day, the general condition of the patient was still poor and she developed edema. Lactated Ringer solution was replaced by dextran at a rate of 60 drops/minute. The body temperature was $36.6^{\circ} \mathrm{C}$, pulse $120 /$ minute, respirations $32 /$ minute, blood pressure $90 / 60$. ECG showed regular sinus rhythm (QRS complex 120/minute). There were no signs of pericarditis.

On the 3rd hospital day, the patient looked better. Edema diminished and the patient gained appetite. Body temperature was $36.4^{\circ} \mathrm{C}$, pulse $102 /$ minute, respirations 28 / minute, blood pressure $110 / 70 \mathrm{mmHg}$. Heart sounds were normal, friction rub was not present.

Chest radiogram in the right lateral decubitus position demonstrated an opaque 
thickening of the right pleura of about 3 $\mathrm{cm}$ and about $1 / 4 \mathrm{~cm}$ of the left pleura. About three fifth of the pleural cavity was filled with fluid. Hazy appearance was observed in left and right hilus. CTR was 0.60 .

A small amount of pericardial effusion was visible on echocardiogram. The intravenous fluid was stopped. Dengue HI antibody titre was $1: 80$ on the first hospital day and increased to 1:320 one week thereafter. On the eight hospital day the patient left the hospital with a normal echocardiogram. The hematrocrit was $34 \%, \mathrm{Hb} 11 \mathrm{~g} / \mathrm{dl}$ and platelets count $200,000 / \mathrm{mm}^{3}$.

\section{Case 2}

M, a Manadonese boy, aged $31 / 2$ years was admitted to the paediatric clinic of Stella Maris Hospital, Ujung Pandang on July 31, 1986 because of irregular fever of seven days duration, running nose and coughing. He vomited frequently and complained of headache, stomach pain and loss of appetite. Diuresis diminished and stool was normal.

Physical examination revealed a severely ill, irritable and wellnourished child (BW $13 \mathrm{~kg}, \mathrm{BH} 98 \mathrm{~cm}$ ). The body temperature was $40^{\circ} \mathrm{C}$, pulse rate was $140 /$ minute and respirations $32 /$ minute. He presented cold and clammy skin.

Examination of heart revealed upper border : 3rd ICS; left border : left medioclavicular line; right border : right parasternal line. The ictus was palpable on the left medioclavicular line. Thrill was not felt. Right and left ventricular activity was normal. Murmur and pericardial friction were not audible.

The lung showed bronchovesicular breathing, no rales. There was no enlargement of the liver and spleen. Echymosis was present on the left lower limb. The lymph nodes were not enlarged.

The haemoglobin was $10.5 \mathrm{gm}$ per $100 \mathrm{ml}$, platelets $80,000 / \mathrm{mm}^{3}$. The haematocrit was on three successive examinations 38 , 39 and $42 \%$, respectively. The chest radiogram in right lateral decubitus position demonstrated a $3 \mathrm{~cm}$ opaque thickening of the right pleura and almost half of the right pleural cavity was filled with fluid. Signs of infiltration were visible in the hilar regions and both paracardial area.

The diagnosis made was DHF grade III and the treatment was Lactated Ringer solution $20 \mathrm{ml} / \mathrm{kg} /$ hour ( 86 drops $/ \mathrm{min}$ ) by vein.

On day 2 the general condition deteriorated, the patient developed edema, the temperature was $36.5^{\circ} \mathrm{C}$, the pulse rose to $120 /$ minute and the respirations $48 /$ minute. The blood pressure was $90 \mathrm{~mm} \mathrm{Hg}$ systolic. Abnormal signs of the heart were not detected. The ECG showed regular sinus rhythm (QRS complex 120/minute). There were no signs of pericarditis. The echocardiogram revealed a small amount of pericardial effusion. Lactated Ringer solution was replaced by dextran at a rate of 42 drops per minute.

On day 3, edema disappeared and the patient looked better, diuresis became normal and the child gained appetite. The temperature was $37.5^{\circ} \mathrm{C}$, the pulse $120 /$ minute and the respirations $32 /$ minute. The blood pressure was $110 / 60 \mathrm{mmHg}$. The intravenous fluid drip was stopped.

On day 7 , the haematocrit was $37 \%$, the haemoglobin was $11 \mathrm{mg}$ per $100 \mathrm{ml}$, and platelets $220,000 / \mathrm{mm}^{3}$. Dengue HI antibody titre was $1: 160$ in serum obtained on admission and became 1:640 in convalescent serum: The echocardiogram showed no pericardial effusion any more and the patient was discharged from the hospital. 


\section{Discussion}

In severe DHF, shock develops acutely and haematocrit value increases due to leakage of plasma through the endothelial wall of the capillaries. This fact can be proved by the accumulation of fluid in the pleural, peritoneal and pericardial cavities which was larger than the amount of solution administered intravenously (Tamaela and Karjomanggolo, 1982).

The clinical manifestations of pericardial effusion vary, depending on the speed of fluid accumulation. Sudden accumulation of fluid may cause severe dyspnoea, cough and stomach pain while an insidious accumulation may give rise to uncharacteristic signs such as mild dyspnoea, ascites and fatigue. In severe cases of pericardial effusion, the heart size enlarges on percussion and ventricular activity in the praecordial area is not visible and heart sounds muffle. Generally friction rub is not heard. The elec- trocardiogram shows low voltage in all leads, inversion of the $\mathrm{T}$ wave and changes of the ST segment (Jordan and Scott, 1973; Nadas, 1969). The chest radiogram illustrates an enlargement of the cardiac silhouette which is sharply defined. It is often possible to see the heart as a separate shadow (Jordan and Scott, 1973). Echocardiography as a non invasive and non traumatic procedure, is the best method for confirming the diagnosis of pericardial effusion. A small amount of fluid $(20 \mathrm{ml})$ can already be detected (Jota, 1963).

In both reported cases, the pericardial effusion was not detected either by physical examination, electrocardiogram or chest radiogram but only on echocardiogram. On the contrary large amounts of fluid can be observed in the pleural cavity by X-ray examination. No satisfactory information is available to explain this phenomenon.

\section{REFERENCES}

1. JORDAN, S.C. and SCOTT, O.: Heart disease in paediatrics; 1st ed., pp 261-263 (Butterworths, London 1973).

2. JOTA, S.: Echocardiographic measurements in normal subjects in Ujung Pandang Tesis UNHAS (1983).

3. NADAS, A.S.: Pediatric cardiology; 2nd ed., pp 93-96, 294-308 (WB Saunders, Philadelphia, London 1969).

4. PARTANA, L.; PARTANA, JS.; THARIR, S.: Hemorrhagic fever shock syndrome in Surabaya J.Med.Sci. Kobe $16:$ 189-201 (1970).
5. SUMARMO: Demam berdarah dengue pada anak di Jakarta Tesis UI (1983).

6. SUMARMO: Dengue hemorrhagic fever. Gambaran klinis, aspek serologis dan virologis. Naskah Lengkap Pendidikan Tambahan Berkala Ilmu Kesehatan Anak di Jakarta, hal 1-19, 1982.

7. TAMAELA, LA.; KARJOMANGGOLO WT.: Peranan pemeriksaan radiologik dalam DHF. Naskah Lengkap Pendidikan Tambahan berkala Ilmu Kesehatan Anak di Jakarta, hal 74-78, 1982. 